\title{
MANAJEMEN PEMBELAJARAN FIQIH DENGAN MENGGUNAKAN METODE AUDIO VISUAL DI MA AL MUWAZANAH GONDANG PLOSOKLATEN KEDIRI
}

\author{
Muhlisin \\ Program Pascasarjana Institute Agama Islam Tribakti Kediri
}

\begin{abstract}
Abstrak
Tersedianya sumber daya manusia (SDM) yang andal antara lain ditandai oleh penguasaan ilmu pengetahuan dan teknologi. SDM ini penting untuk dikembangkan di suatu Negara berkembang termasuk di Indonesia, khususnya di institusi pendidikan. Karena embrio kemajuan suatu bangsa dimulai dari sektor pendidikan.

Penguasaan ilmu pengetahuan yang menandai SDM di sekolah adalah guru yang menguasai metode pembelajaran yang andal. Di antaranya metode pembelajaran yang mutakhir adalah metode dengan menggunakan audio visual.

Permasalahan yang peneliti ajukan dalam penelitian ini antara lain: 1. Apa yang direncanakan dalam pembelajaran fiqih dengan menggunkan media Audio Visual di MA Al Muwazanah Gondang Plosoklaten 2. Bagaimana pengorganisasian pembelajaran fiqih dengan menggunkan media Audio Visual di MA Al Muwazanah Gondang Plosoklaten Kediri, 3.Bagaimana pengimplementasian pembelajaran fiqih dengan menggunkan media Audio Visual di MA Al Muwazanah Gondang Plosoklaten Kediri.

Jenis penelitian ini adalah kualitatif, sebagaimana arahan jenis penelitian kualitatif, maka data yang terkumpul kemudian dianalisis berdasar teori - teori yang diketemukan guna menarik sebuah kesimpulan yang sesuai dengan maksud diadakannya suatu penelitian tersebut.

Berdasarkan pembahasan diatas, terkait dengan pelaksanaan pembelajaran dengan menggunakan metode audio visual, dapat disimpulkan 1) Perencanaan. yaitu proses penetapan dan pemanfaatan sumber daya secara terpadu yang diharapkan dapat menunjang kegiataan dan upaya-upaya yang akan dilaksanakan secara efisien dan efektif dalam mencapai tujuan. 2) Pengorganisasian. Yaitu Merupakan upaya untuk menghimpun semua sumber daya yang dimiliki daerah dan memanfaatkannya secara efisien guna mencapai tujuan (goals) yang telah ditetapkan. Dalam pengorganisasian (organizing) harus pula diperhatikan adalah menentukan siapa melakukan apa (staffing). 3) Evaluasi. Yaitu suatu proses yang direncanakan untuk memporoleh data atau informasi yang di gunakan merumuskan tujuan pembelajaran, memperbaiki belajar siswa dan sejauh mana proses pencapaian pembelajaran siswa agar siswa menapai tujuan yang di harapkan oleh pendidik.
\end{abstract}

Kata Kunci: Manajemen Pembelajaran,Metode Audio Visual

\section{A. Konteks Penelitian}

Tersedianya sumber daya manusia (SDM) yang andal antara lain ditandai oleh penguasaan ilmu pengetahuan dan teknologi. SDM ini penting untuk dikembangkan di suatu Negara berkembang termasuk di Indonesia, khususnya di institusi pendidikan. Karena embrio kemajuan suatu bangsa dimulai dari sektor pendidikan.

Penguasaan ilmu pengetahuan yang menandai SDM di sekolah adalah guru yang menguasai metode pembelajaran yang andal. Di antaranya metode pembelajaran yang mutakhir adalah metode dengan menggunakan audio visual.

Masalah yang muncul dalam sektor 
pendidikan adalah seberapa besar pemanfaatn audio visual telah digunakan dalam system pembelajaran. Pemanfaatan aiudio visual diharapkan dapat meningkatkan hasil belajar siswa. Baik yang berupa hasil belajar beruapameningkatnya kecerdasan maupun berupa cara belajar yang lebih efektif.

Dari uraian latar belakang masalah diatas, maka penulis dalam penelitian ini mengambil judul "Manajemen pembelajaran fiqih dengan menggunakan metode Audio Visual (LCD) di MA Al Muwazanah Gondang Plosoklaten Kediri Tahun Pelajaran 2015-2016”.

\section{Fokus Penelitian}

Fokus penelitian ini ada tiga hal yakni 1) Apa yang direncanakan dalam pembelajaran fiqih dengan menggunakan metode Audio Visual (LCD) di MA Al Muwazanah Gondang Plosoklaten Kediri. 2) Bagaimana pengorganisasian pembelajaran fiqih dengan menggunakan metode Audio Visual di MA Al Muwazanah Gondang Plosoklaten Kediri. 3) Bagaimana evaluasi pembelajaran fiqih dengan menggunakan metode Audio visual (LCD) di MA Al Muwazanah Gondang Plosoklaten Kediri.

\section{Tinjauan Tentang Manajemen Pembelajaran}

Manajemen Pembelajaran adalah kegiatan menangani, mengurus, mengendalikan, mengarahkan ,mengawasi, membimbing, dan menyelesaikan sesuatu guna mencapai tujuan tertentu.Kegiatan tersebut dilakukan dalam wujud pengelolaan organisasi, proyek atau kelembagaan sedemikian rupa,di dalamnya berkumpul sejumlah orang yang tengah melakukan kerja sama, dan pemimpin utamanya dikenal dengan sebutan manajer ${ }^{1}$.

Tujuan manajemen pembelajaran erat sekali dengan tujuan pendidikan secara umum, karen manajemen pendidikan pada hakikatnya merupakan alat untuk mencapai tujuan pendidikan secara optimal. Apabila dikaitkan dengan pengertian manajemen pendidikan pada

1 .BAWANI,Prof.DR.H.Imam Bawani.MA,Metodologi Penelitian Pendidikan Islam (Sidoarjo:KHAZANAH ILMU SIDOARJO,2016),285 hakikatnya merupakan alat mencapai tujuan.

\section{Tujuan Pokok Mempelajari Manajemen Pembelajaran}

Tujuan pokok mempelajari manajemen pembelajaran adalah untuk memperoleh cara, teknik dan metode yang sebaik-baiknya dilakukan, sehingga sumber-sumber yang sangat terbatas seperti tenaga, dana, fasilitas, material maupun spiritual guna mencapai tujuan pembelajaran secara efektif dan efisien.

Nanang Fattah berpendapat bahwa: Tujuan ini tidak tunggal bahkan jamak atau rangkap, seperti peningkatan mutu pendidikan/ lulusanya, keuntungan/profit yang tinggi, pemenuhan kesempatan kerja membangun daera/nasional, tanggung jawab sosial. Tujuantujuan ini ditentukan berdasarkan penataan dan pengkajian terhadap situasi dan kondisi organisasi, seperti kekuatan dan kelemahan, peluang dan ancaman. ${ }^{2}$ Dalam keseluruhan proses pendidikan di sekolah, pembelajaran merupakan aktivitas yang paling utama. Ini berarti bahwa keberhasilan pencapaian tujuan pendidikan banyak tergantung pada proses pembelajaran yang baik. Pembelajaran ialah membelajarkan siswa menggunakan asas pendidikan maupun teori belajar, yang merupakan penentu utama keberhasilan pendidikan. Pembelajaran merupakan proses komunikasi dua arah, mengajar dilakukan oleh pihak guru sebagai pendidik, sedangkan belajar dilakukan oleh peserta didik atau murid.

Sedangkan menurut Corey: "Pembelajaran adalah suatu proses dimana lingkungan seseorang secara disengaja dikelola untuk memungkinkan ia turut serta dalam tingkah laku tertentu dalam kondisi-kondisi khusus atau menghasilkan respons terhadap situasi tertentu, pembelajaran merupakan subset khusus dari pendidikan."3

Dalam pengertian demikian dapat dikatakan bahwa pembelajaran adalah upaya membelajarkan siswa untuk belajar. Kegiatan

2 Nanang Fattah, Landasan Manajemen Pendidikan, (Bandung: PT. Remaja Rosdakarya, 2004), 15

3 Syaiful Sagala, Konsep dan Makna Pembelajaran (Bandung : Alfabeta, 2003), 61 
ini akan mengakibatkan siswa mempelajari sesuatu dengan cara lebih efektif dan efisien.

Fiqih merupakan pengetahuan tentang hukum-hukum syariat Islam mengenai perbuatan-perbuatan manusia, yang diambil dari dalil-dalil secara terinci. ${ }^{4}$ Jadi, Ilmu fiqih bertujuan untuk memberi pelajaran, pengetahuan, atau petunjuk tentang hukum, apa yang disuruh dan apa yang dilarang, mana yang boleh dan mana yang tidak, serta menunjukkan cara melaksanakan suatu perintah ajaran Islam. Sebagaimana lazimnya suatu bidang studi yang diajarkan di Madrasah, materi keilmuan mata pelajaran fiqih mencakup dimensi pengetahuan (knowledge), keterampilan (skill), dan nilainilai(value). ${ }^{5}$

\section{A. Tinjauan Tentang Metode Audio Visual}

Metode Audio Visual adalah cara yang mudah dan optimal bagi siswa dalam menyerap informasi yang diterima dalam proses belajar mengajar.Metode belajar yang dimaksud adalah Metode Audio Visual : belajar dengan cara melihat, ${ }^{6}$.

Audio-visual adalah alatalat"audible"artinya dapat didengar danalatalat"visible"artinya dapat dilihat. Alat-alat audio-visual gunanya untuk membuat cara berkomunikasi menjadi efektif. Media audiovisual merupakan bentuk media pengajaran yang terjangkau. ${ }^{7}$

Teknologi audio-visual merupakan cara untuk menghasilkan atau menyampaikan materi dengan menggunakan mesin-mesin mekanis dan elektronik untuk menyajikan pesan-pesan audio-visual. Pengajaran melalui media audio-

4 Abdul Majid dan Dian Andayani,Pendidikan Agama Islam Berbasis Kompetensi(Bandung: PT Remaja Rosdakarya, 2006) cet ke 2, hal 130

5 Universitas Ria Fauzia Hanum,"Strategi Pembelajaran Contextual Teaching and Learning(CTL)dalam Mewujudkan Life Skill Siswa pada Mata Pelajaran Fiqih di MTs Surya Buana Malang",Skripsi,Fakultas Tarbiyah Islam Negeri Malang.

6 Bobby De porter. Dan Mike Hernacki, Quantum Learning, Membiasakan Belajar Nyaman dan

Menyenangkan, (Bandung: Kaifa, 2002), 113

7 .Amir hamzah,Media Audio-Visual.(Jakarta: PT Gramedia, 1985) hlm. 11 visual jelas bercirikan pemakaian perangkat keras selama proses belajar seperti: televisi, tape recorder, dan proyektor visual yang lebar. ${ }^{8}$

Tulisan dan ucapan sangat bermanfaat dalam situasi belajar pada umumnya, tetapi ada beberapa konsep yang tidak dapat disampaikan sejelas atau selengkap jika menggunakan alat bantu audio-visual.

\section{Pembelajaran Fiqih dengan menggunakann Metode Audio Visual}

Sebelum menjelaskan mengenai pengembangan audio visual pembelajaran fiqih, terlebih dahulu akan penulis paparkan beberapa prinsip dalam mendesain yang seharusnya digunakan dengan konsisten. Prinsip-prinsip itu antara lain:

\section{Prinsip Keterdekatan Ruang}

Murid-murid bisa belajar lebih baik saat kata-kata dan gambar-gambar terkait disajikan saling berdekatan daripada saling berjauhan dihalaman atau layar.

2. Prinsip Keterdekatan Waktu

Murid-murid bisa belajar lebih baik saat kata-kata dan gambar-gambar terkait disajikan secara bebarengan daripada bergantian.

3. Prinsip Perbedaan Individual

Pengaruh desain lebih kuat terhadap murid-murid berpengetahuan rendah daripada berpengetahuan tinggi ${ }^{9}$. Prinsipprinsip yang berorienasi pada murid-murid tersebut secara berkelanjutan kita gunakan terutama dalam rangka mengembangkan kemampuan kognitif siswa. Sebab siswa memiliki kemampuan sebagai penalar aktif yakni secara aktif memproses kata-kata dan gambar-gambar yang masuk melalui saluran auditori dan saluran visual yang kapasitasnya sangat terbatas.

\section{Metode Penelitian}

Dalam penelitian ini, peneliti menggunakan metode penelitian Kualitatif,

8 . Azhar Arsyad,op. cit, hlm 30

9 Richard E. Mayer, Multimedia learning, (t.tp., t.th.p), 270-271. 
yang mana menurut margono yang mengacu pada pendapat Bodgan dan Taylor, penelitian kualitatif adalah prosedur penelitian yang menghasilkan data deskriptif berupa kata - kata tertulis dari orang - orang dan perilaku yang dapat di amati. ${ }^{10}$

Selain itu dalam penelitian ini, peneliti sebagai instrumen kunci (research as key instrument); yaitu peneliti mengumpulkan sendiri data melaluidokumentasi, observasi perilaku, atau wawancara dengan para partisipan. ${ }^{11}$

\section{Lokasi Penelitian}

Tempat penelitian yang dipilih adalah MA AL MUWAZANAH yang berada di Desa Gondang Kecamatan Plosoklaten Kabupaten Kediri yang merupakan salah satu dari beberapa lembaga pendidikan swasta yang terdapat pada daerah tersebut.

\section{A. Perencanakan dalam pembelajaran fiqih dengan menggunakan metode Audio Visual (LCD) di MA Al Muwazanah Gondang Plosoklaten Kediri}

Pada tahap perencanaan pembelajaran audio visual terdapat beberapa kegiatan yaitu: 1) Mengembangkan Tujuan. Tujuan ini untuk merencanakan media pembelajaran yang efektif dan pengalaman belajr lainnya, haruslah diketahui secara khusus apa yang akan dipelajari. Kegunaan dari memformulasikan tujuan adalah menyediakan petunjuk yang jelas apa yang harus dimuat dan ke mana arah dari suatu presentasi. Ada tiga kelompok tujuan pembelajaran, yaitu: a) Kognitif- berhubungan dengan pengetahuan dan informasi. Afektif berhubungan dengan sikap, apresiasi dan nilai, b) Psikomotor berhubungan dengan keterampilan, c) Selain mengarahkan belajar dan materi pelajaran yang harus diberikan, perumusan tujuan berguna pula sebagai acuan membuat tes agar apa yang telah dirumusakan dapat diukur dengan tepat.

10 Margono.S (2009), Metode Penelitian Pendidikan, Rineka Cipta, Jakarta,36.

11 Jhon W. Creswell (2010), RESEARCH DESIGN: Pendekatan Kulitatif, Kuantitatif, Dan Metode Campuran, PUSTAKA BELAJAR, Yogyakarta, 261.
Semetara persiapan penggunaan audio visual mempertimbangkan: a) Mempertimbangkan Audience. Karakteristik siswa atau audience, yaitu mereka yang akan melihat, menggunakan dan belajar dari media yang kita buat, tidak dapat dipisahkan dari perumusan tujuan yang kiya buat. Karakteristik audience seperti usia, tingkat pendidikan, pengetahuan terhadap subyek, keterampilan, sikap, konteks budaya, perbedaan individual, kesemuanya perlu diperhatiakan dalam membuat tujuan dan topik bahasan. Perimbangan tentang audience ini merupakan hal yang dominan manakala kita mempertimbangkan kompleksitas ide, topik, kosakata, contoh-contoh dan tingkat partisipasi siawa yang di harapkan. Karena daya tangkap siswa berbeda - beda ada yang audiktif (cenderung lebih senang mendengarkan suara) dan ada yang lebih cepat dengan melihat gambar/tampilan sesuatu.

b) Membuat dan memilih video/film/slide dalam sebuah team Mengerjaka suatu media pembelajaran bersama-sama adalah ide yang sengat baik. Kita dapat berbagai ide, kreativitas, dan keahlian lainnya sehingga media yang kita buat akan lebih efektif, kreatif, dan menarik. Misalnya, dalam pembuatan media audio audio visual, satu kelompok pembuat media dapat terdiri dari ahli disain gambar, ahli efek suara, ahli materi dan ahli penggabungan film.

\section{B. Pengorganisasian dalam pembelajaran fiqih dengan menggunakan metode Audio Visual (LCD) di MA Al Muwazanah Gondang Plosoklaten Kediri}

Dalam pengorganisasian pembelajaran meliputi beberapa kegiatan yaitu: 1) Menata bahan ajar yang akan diberikan selama satu semester. 2) Menata bahan ajar yang akan diberikan setiap kali pertemuan. 3) Memberikan pokok-pokok materi kepada siswa yang akan diajarkan. 4) Membuat rangkuman atas materi yang diajarkan setiap kali pertemuan. 5) Menetapkan materimateri yang akan dibahas secara bersama. 6) Memberikan tugas kepada siswa 
terhadap materi tertentu yang akan dibahas secara mandiri. Dan 7) Membuatkan format penilaian atas penguasaan setiap materi.

\section{Evaluasi dalam pembelajaran fiqih dengan menggunakan metode Audio Visual (LCD) di MA Al Muwazanah Gondang Plosoklaten Kediri}

Guru harus memandang media pendidikan sebagai alat bantu utama untuk menunjang keberhasilan belajar dan memperkembangkan metode-metode yang dipakainya dengan memanfaatkan media tersebut yaitu media audio visual yang merupakan bentuk media pengajaran yang terjangkau.

Berkaitan dengan tujuan guru dalam menggunakan media audio visual pada mata pelajaran fiqih ini peniliti melakukan wawancara guru yang mengajar mata pelajaran fiqih dan hasilnya sebagai berikut: "Tujuan saya menggunakan media ini untuk meningkatkan kualitas anak dalam proses belajar mengajar, memudahkan siswauntuk belajar, memotivasi siswa supaya lebih giat lagi untuk belajar, dan dapat menghasilkan prestasi yang lebih baik. Karena dengan menggunakan media guru lebih mudah menjelaskan tentang isi materi pelajaran fiqih. Begitu dengan siswa lebih memahami menggunakan media audio visual seperti televisi,video, LCD, dan komputer daripada menggunakan mediagambar, sebab media audio visual mengandung dua unsur yaitu mengamati dan mendengar. Untuk menghasilakan belajar siswa dengan baik, setelah praktek dengan menggunakan media audio visual, saya menyuruh siswa untuk merangkum atau menyimpulkan materi tersebut, supaya guru mengetahui seberapa jauh siswa mengamati materi dengan menggunakan media audio visual"menggunakan kurikulum tingkat satuan pendidikan (KTSP)". ${ }^{12}$

\section{Manajemen Pembelajaran Fiqih dengan menggunakan Metode Audio Visual}

Penggunaan media audio visual dalam meningkatkan hasil belajar padamata pelajaran

12 Wawancara denganAry Wahyudi M.Pd.I. Guru PAI (Fiqih) MAAI Muwazanah Kediri, tanggal 5 april 2015 fiqih merupakan suatu pembelajaran yang dilkukan oleh guru dan siswa dengan menggunakan media atau alat-alat yang audible artinya bisa didengar dan alat visible artinya bisa dilihat.

Tujuanmenggunakanmediaadalahmenggunakan media audio visual dalam mata pelajaran fiqih sangat mendukung siswa untuk lebih giat belajar dan dapat mempermudah mempelajari pesan atau pelajaran, membangkitkan semangat siswa, dan mempermudah guru dalam menyampaikan pesan atau pelajaran dan meningkatkan motivasi siswa serta menciptakan siswa yang berintelektual dalam menggunakan teknologi.

Begitu juga dengan tujuan guru menggunakan media audio visual adalah guru harus memandang media pendidikan sebagai alat bantu utama untuk menunjang keberhasilan belajar dan memperkembangkan metode-metode yang dipakainya dengan memanfaatkan media tersebut yaitu media audio visual yang merupakan bentuk media pengajaran yang terjangkau. Tugas guru di sini adalah mengajar, mendidik, melatih, dan mengevaluasi. Karena pengajaran agama lebih bernuansa "abstrak" Maka penggunaan alat peraga harus dilakukan secara bijaksana, sehingga jangan sampai siswa malah menjadi bingung dan kacau pengertian dan pemahamannya setelah mendapatkan penyampaian materi.

Pada mata pelajaran fiqih, materi yang menggunakan media audio visual adalah materi shalat, thaharah, puasa, haji. Karena materi ini merupakan rukun Islam yang paling penting untuk dipelajari. Siswa harus benar-benar memahami isi atau kandungan materi tersebut.

\section{Proses Penggunaan Media Audio Visual pada Mata Pelajaran Fiqih di MA Al Muwazanah}

Sebagaimana data yang diperoleh dari lapangan bahwasannya guru pendidikan agama Islam dalam menggunakan media audio visual ialah harus dengan waktu semaksimal mungkin, dan guru dapat memanfaatkan serta menggunakan media audio visual dengan baik. Langkah-langkah guru untuk menggunakan media audio visual dalam pembelajaran harus ada persiapan, pelaksanaan dan kegiatan lanjutan supaya guru dan siswa dapat berinteraksi dengan baik. Misalnya, dalam mata pelajaran fiqih guru harus mepersiapkan tema-tema yang disampaikan kepada siswa seperti, Thaharah, sholat, puasa, haji dan 
sebagainya. Belajar dengan alat bantu audio visual dapat ditingkatkan secara langsung dan dianjurkan oleh guru dengan cara: 1) Memperkenalkan bahan dan menyebutkan tujuan yang harus dicapai. 2) Menganjurkan partisipasi siswa, khususnya siswa yang berkemampuan tinggi,(ada suatu anjuran yang samar-samar dalam literatur bahwa siswa yang IQ-nya rendah dapat belajar lebih banyak, jika dia belajar tanpa secara aktif menjawab atau memberikan respon terhadap alat bantu audio visual seperti film dan televisi).

Cara-cara diatas penting, karena mengandung pengertian bahwa audio visual pantas digunakan dengan baik. Disamping itu, karena jumlah belajar yang sebenarnya bergantung dari tujuan belajar serta dapat menentukan criteria pemakaian media oleh guru.

Salah satu dari informan, yaitu guru yang mengatasi bagian sarana prasarana mengatakan "Sudah 1 tahun MAAl Muwazanah mempunyai media audio visual. Mulai dari 2015 sampai sekarang MA Al Muwazanah mendapat kemajuan, dari tahun ke tahun sarana yang ada di MA Al Muwazanah selalu bertambah, tetapi guru pendidikan agama jarang menggunakan media tersebut, hanya sebagian guru yang sudah menggunakannya. Dan waktunya harus terjadwal, untuk les 1 kali dalam seminggu supaya siswa lebih cepat, pintar, cermat dalam menggunakan teknologi”.

Begitu juga dengan guru pendidikan agama Islam menjelaskan,"Untuk menghasil kanperoses belajar mengajar dengan baik, setelah Praktek menggunakan media audiovisual, yang saya lakukan ialah menilai siswa dengan mengadakan pretes,merangkum, dan menyimpulkan tentang materi yang berhubungan dengan fiqih.Karena saya ingin mengetahui sejauhmana siswa menanggapi pelajaran fiqih,disamping itu saya juga mengetahui mana siswa yang serius dan mana siswa yangtidak serius dalam mengikuti pembelajaran, dengan adanya evaluasi saya lebih mudah memahami tingkah laku siswa"

Hasil Belajar Siswa setelah Guru Menggunakan Media Audio Visual pada Mata Pelajaran Fiqih di MA Al Muwazanah Gondang Plosoklaten Kediri
Dari data yang diperoleh, setelah guru menggunakan media audio visualpada mata pelajaran fiqih maka guru mengadakan evaluasi hasil belajar yang merupakan proses untuk menentukan nilai belajar siswa melalui kegiatan penilaian dan pengukuran hasil belajar. Tujuannya untuk mengetahui kemajuansiswa dalam suatu kurun waktu proses belajar tertentu. hal ini berarti dengan evaluasi guru dapat mengetahui kemajuan perubahan tingkah laku siswa sebagaihasil proses belajar dan mengajar yang melibatkan dirinya selaku pembimbing dan pembantu kegiatan belajar siswa.Untuk menghaslkan nilai yang baik guru melakukan evaluasi formatif danevaluasi sumatif.

Yang dimaksud dengan evaluasi formatif adalah penilaian yangdilaksanakan pada akhir program belajar mengajar untuk melihat tingkat keberhasilan proses belajar mengajar itu sendiri.

Dengan demikian, penilaianformatif berprentasi kepada proses belajar mengajar,. Dengan penilaian formatif diharapkan guru dapat memperbaiki program pengajaran dan strategi pelaksanaanya, sedangkan evaluasi sumatifadalah penilaian yang dilaksanakanpada akhir unit program, yaitu akhir catur wulan, akhir semester dan akhir tahun.

Tujuannya adalah untuk melihat hasil yang dicapai oleh siswa, yakni seberapa jauh tujuantujuan kurikuler dikuasai oleh siswa.Jadi, hasil belajar siswa setelah guru menggunakan media audio visualpada mata pelajaran fiqih sangat baik sekali, rata-rata siswa banyak mendapat hasil yang baik.

Dengan begitu penggunaan media audio visual pada mata pelajaran fiqih sangat bermanfaat sekali bagi guru dan siswa, karena guru lebih mudah menjelaskan materi-materi tentang fiqih dan menjadikan siswa yang pintar, cermat dan berintelektual.

\section{Kesimpulan}

Berdasarkan pembahasan diatas, terkait dengan pelaksanaan pembelajaran dengan menggunakan metode audio visual, dapat disimpulkan 1) Perencanaan. yaitu proses 
penetapan dan pemanfaatan sumber daya secara terpadu yang diharapkan dapat menunjang kegiataan dan upaya-upaya yang akan dilaksanakan secara efisien dan efektif dalam mencapai tujuan. 2) Pengorganisasian. Yaitu Merupakan upaya untuk menghimpun semua sumber daya yang dimiliki daerah dan memanfaatkannya secara efisien guna mencapai tujuan (goals) yang telah ditetapkan. Dalam pengorganisasian (organizing) harus pula diperhatikan adalah menentukan siapa melakukan apa (staffing). 3) Evaluasi. Yaitu suatu proses yang direncanakan untuk memporoleh data atau informasi yang di gunakan merumuskan tujuan pembelajaran, memperbaiki belajar siswa dan sejauh mana proses pencapaian pembelajaran siswa agar siswa menapai tujuan yang di harapkan oleh pendidik.

\section{DAFTAR PUSTAKA}

Abdul Majid dan Dian Andayani, 2006) Pendidikan Agama Islam Berbasis Kompetensi(Bandung: PT Remaja Rosdakarya,

Ahmad Rohani,(2007). Media Intruksional Edukatif , (Jakarta: PT. Raja GrafindoPersada.

Amir hamzah, , (1985)Media Audio-Visual. (Jakarta: PT Gramedia

Arif Sadiman, (2007). Media Pendidikan. (Jakarta: PT. Raja Grafindo Persada

Azmawir, Basyaruddin (2002)Usman.Media Pembelajaran. ( Jakarta: Ciputat Pers

Bawani, Imam Bawani.(2016) Metodologi Penelitian Pendidikan Islam. KHAZANAH ILMU. Sidoarjo.

Bobby De porter. Dan Mike Hernacki, (2002), Quantum Learning, Membiasakan Belajar Nyaman dan Menyenangkan, Kaifa, Bandung.

Bobby De porter. Dan Mike Hernacki, 2002. Quantum Learning, Membiasakan Belajar Nyaman dan enyenangkan. Bandung: Kaifa
Fatah syukur (2011) Manajemen Pendidikan,pustaka rizki putra,Semarang.

Hamzah B. Uno, (2006) Orientasi dalam Psikologi Pembelajaran (Jakarta: PT. Bumi Aksara,

asan Shadily, Ensiklopedi Indonesia, (Ictiar Baru - Van Hoeve dan Elsevier Publishing Projects, t.t), Jakarta.

Husaini Usman, Manajemen Teori, Praktik, dan Riset Pendidikan, (Jakarta: Bumi Aksara, 2006).

Ivon K Davies,Pengelolaan Belajar (Jakarta: Rajawali Pers 1991.

Jhon W. Creswell (2010), Research Design: Pendekatan Kulitatif, Kuantitatif, Dan Metode

Campuran, PUSTAKA BELAJAR, Yogyakarta.

Lexy J. Moleong (1995), Metode Penelitian Kualitatif,Remaja Rosdakarya, Bandung.

Malayu S.P. Hasibuan, (2011) Manajemen: Dasar, Pengertian, dan Masalah, (Jakarta: Bumi Aksara,

Mansur Mukhlis (2009), Melaksanakan PTK Itu Mudah, Bumi Aksara, Jakarta.

Margono.S (2009), Metode Penelitian Pendidikan, Rineka Cipta,Jakarta

Muhaimin dkk,Strategi Belajar Mengajar(Surabaya: Citra Media,.

Muhammad Nazir (1998), Strategi Penelitian, Ghalia Indonesia,Jakarta.

Nanang Fattah, (2004) Landasan Manajemen Pendidikan, (Bandung: PT. Remaja Rosdakarya,

Siti Kusrini, dkk. (2005) Keterampilan Dasar Mengajar (PPL 1), Berorientasi Pada Kurikulum Berbasis Kompetensi (Malang: Fakultas Tarbiyah UIN Malang

Sukandarrumidi (2004), Metodologi Penelitian PetunjukPraktisUntuk Peneliti Pemula, Gadjah Mada University Press, Yogyakarta. 
intëlëktuãl | Vol. 7, No. 1, Mei 2017: 109 - 116

Suprijanto. (2007)Pendidikan Orang Dewasa dariTeori hingga Aplikasi(Jakarta: Bumi Aksara

Syaiful Bahri Djamarah, (2002) Azwan Zaian,Strategi Belajar Mengajar (Jakarta: RinekaCipta,

Syaiful Sagala, (2003) Konsep dan Makna Pembelajaran (Bandung : Alfabeta,
Syaiful Sagala, (2008) Konsep dan Makna Pembelajaran(Bandung: Alfabeta,

Team Didaktik Metodik Kurikulum IKIP Surabaya. (1995),Metodik Kurikulum Proses Belajar Mengajar . Jakarta: PT. Grafindo Persada, 1994). 